\title{
Erratum \\ Relation of C-reactive protein and other cardiovascular risk factors to penile vascular disease in men with erectile dysfunction
}

AJ Bank, KL Billups, DR Kaiser, AS Kelly, RA Wetterling, MY Tsai and N Hanson

International Journal of Impotence Research (2003) 15, 388. doi:10.1038/sj.ijir.3901100

Correction to: International Journal of Impotence Research (2003) 15, 231-236.

Due to an oversight, the authors' names were published in the incorrect order. The correct order should read:

KL Billups, DR Kaiser, AS Kelly, RA Wetterling, MY Tsai, N Hanson and AJ Bank 